\title{
НАСЛЕЪЕ А. С. ПУШКИНА КАО „МОСТ“ ИЗМЕЂУ СОВЈЕТСКОГ САВЕЗА И КРАљЕВИНЕ ЈУГОСЛАВИЈЕ 1933-1935. ГОДИНЕ
}

Током 20-их и 30-их година 20. века може се уочити повећано интересовање југословенских уметника и интелектуалаца за Совјетску Русију. Та радозналост је од стране Совјета коришћена у сврху формирања повољнијег јавног мњења у иностранству. У оквиру те кампање одвили су се скоро сви међуратни контакти совјетских установа и појединих Југословена. Са тачке гледишта очувања руског културног наслеђа најзначајнији међу тим контактима је преписка између директора московског Музеја књижевности Владимира Бонч-Брујевича и преводиоца Јована Максимовића (1933). То дописивање је за резултат имало повратак у Москву рукописа А. С. Пушкина, познатог као „Свеске Всеволожског“.

Кључне речи: Пушкинов рукопис, „Свеска Всеволожског“, Владимир Бонч-Брујевич, Јован Максимовић, Руско-Српске културне везе

Бољшевички преврат и Грађански рат у Русији (19171920) довели су, поред осталог, до прекида традиционалних државних и политичких односа између руског и српског народа. Тек 1940. године отворена су дипломат- 
ска представништва у Београду и Москви. Што се тиче руско-српских културних и верских веза, оне су се одржавале захваљујући одлуци југословенског двора и владе да пруже азил десетинама хиљада Руских избеглица. (Јовановић 1996; Йованович 1996, 2005; Козлитин 1998) Међутим, упркос њиховом масовном присуству у Краљевини $\mathrm{CXC}$, током читавог међуратног времена уочава се интересовање југословенских и српских интелектуалних кругова (не само левичара) за Совјетску Русију. Од ње се очекивало да ће, са једне стране, послужити као пример новог напредног друштва и, истовремено, наследити цивилизацијску улогу старе Русије. Од стране Совјета таква радозналост је коришћена у сврхе формирања повољнијег јавног мњења у иностранству, односно улепшавања сопствене лоше репутације. У оквиру те кампање одвили су скоро сви међуратни културни контакти совјетских установа са једне стране и појединих југословенских интелектуалаца и уметника са друге стране .(Јовановић 2011; Радоевич 2014; Милорадовић 2017)

Са тачке гледишта очувања и проучавања руског културног наслеђа назначајнији међу свим тим контактима била је преписка између Владимира Бонч-Брујевича $^{1}$ - истакнутог бољшевика, директора московског Музеја књижевности, и Јована Максимовића - филолога и преводиоца са Руског. Данас је та преписка део грађе руског архива литературе и уметности는 Дописивање је

1 Бонч-Брујевич, Владимир Димитријевич (1873-1955) - револуционар, бољшевик, совјетски партијски и државни делатник, писац. Сарадник В. И. Лењина. Активно учествовао у револуцији (1917) и Грађанском рату (1918-1920). После смрти Лењина изашао из политике. Иницијатор оснивања и први директор (1933-1945) Државног литерарног музеја у Москви (Государственный литературный музей).

2 Российский государственный архив литературы и искусства (Даље: РГАЛИ). Ф. 612, Государственный литературный музей. 
започело у октобру 1933. и имало је за резултат повратак у Москву у јануару 1934. године рукописа А. С. Пушкина, познатог као „Свеска Всеволожско““ (Летописи Государственного литературного музея; Материалы по истории первого собрания стихотворений Пушкина).

Пре него што пређемо на историју њиховог проналажења, треба објаснити одакле потиче интерес за дореволуционарног песника, кога је совјетска власт, по речима Мајаковског ${ }^{3}$, „бацила са пароброда савремености“, заједно са свом осталом „реакционарном“/,великодржавном“ руском историјом и културом. Разуме се, доносећи решење о набавци манускрипта, Бонч-Брујевич се није руководио сопственим литерарним склоностима. У тоталитарној држави, каква је био СССР, ништа се није дешавало мимо воље врховног управљача. А он је на прелазу из из двадесетих у тридесете године иницирао „рехабилитацију одабраних познатих личности и општепризнатих симбола руске националне прошлости“. (Бранденбергер 2009: 15) Популаризација Пушкина, Љермонтова, Гогоља или Толстоја имала је пропагандне циљеве. Док су читале патриотска дела посвећена побе-

\footnotetext{
Бољшевичко схватање Пушкина као „класно туђег“ песника нашло је одраза у песми Мајаковског „Рано је за радовање“ (1918. г):

$$
\begin{gathered}
\text { Белогардејца } \\
\text { нађете - па уза зидић. } \\
\text { А Рафаела заборависте? } \\
\text { Заборависте и Растрела? } \\
\text { Време је } \\
\text { да се куршумима } \\
\text { сенчи по зидовима музеја. (...) } \\
\text { Поређали топове украј, } \\
\text { глуви за белогардејско улагивање. } \\
\text { А зашто } \\
\text { није нападнут Пушкин? } \\
\text { А остали } \\
\text { генерали класике? }
\end{gathered}
$$
}


дама руског оружја над Швеђанима и Французима, масе је обузимао осећај љубави према њиховој „социјалистичкој отаџбини“. А то је, по речима већ цитираног америчког историчара Дејвида Бранденбергера, властима олакшавало задатак „мобилизације масовне подршке друштва“. Оно је, десет година после револуције, почело да показује слабу пријемчивост за идеалистичке и утопистичке пароле „марксизма-лењинизма у чистом облику“.

Што се Пушкина тиче, кампања за његово увођење у официјелни идеолошки „Пантеон“ достигла је своју кулминацију 1937. године. На врхунцу „Великог терора“ одвијало ce и празновање (sic!) стоте годишњице песникове погибије. С тим ,јубилејем“ био је усклађен и почетак издавања његових сабраних дела, од којих је први том изашао 1937, а последњи (шеснаети) - 1949. године. Публиковање канонске варијанте Пушкинових дела изискивало је приступ његовим рукописима, од којих су многи сматрани неповратно изгубљеним. Онај којим ћемо се касније бавити, по речима совјетског историчара књижевности Л. Л. Домгера, „одиграо је важну улогу приликом успостављања хронологије исправки које је, у различитим периодима“ (1987), Пушкин уносио у текст својих раних стихова. Шта, у ствари, представља „Свеска Всеволожског“?

Најкраће речено, тај рукопис је зборник песама који је Пушкин почетком 20-их година 19. века био припремао за штампу, али га је прокоцкао или поклонио свом пријатељу Никити Всеволожском. Лутања тог рукописа по Русији и његов пут у Србију дуга су и контроверзна прича. Међутим, са сигурношћу можемо да кажемо да су се свеске у другој половини XIX века нашле у власништву пуковника Српске војске Ђоке Влајковића, који је претходно служио као Аустријски и Руски официр. После смрти пуковника његов легат се чувао у Српском државном архиву. О томе, већ по повратку рукописа у Москву, Бонч-Брујевичу пише 
из Прага чувени руски слависта Владимир Францев ${ }^{4}$, који је 1912. године, током боравка у Београду, користио збирку „Писма великих књижевника“ (Москва-Сербия, Белград-Россия: 426). На жалост, после Првог светског рата збирци се губи сваки траг.

Пушкинов рукопис је поново испливао на површину 1933. године, у кући некада имућне београдске породице Обрадовић. Ситан чиновник Министарства спољних послова, Миодраг Обрадовић, који је већ био потрошио дедин и татин капитал, „дошао је - према писању 'Политике' - на мисао да би се ствар могла уновчити. Па како је у једном ужем кругу професор Максимовић радо сматран као зналац руске књижевности, рукопис је однесен њему на проучавање“. (Политика. 12 Јануар 1934) Треба нагласити да ауторство рукописа Максимовић није одредио сам, него уз помоћ руских професора Београдског универзитета - Александра Погодина и Лава Сухотина.

Максимовић је 1. јула 1933. године писао у Лењинград - руководству тзв. Пушкинског дома (Институт Руске Књижевности Академије Наука). У писму се није налазио само предлог да се откупи рукопис, него и драгоцени прилог - фотографије неколико страница манускрипта. Тек у октобру стиже одговор са потписом истакнутог совјетског историчара књижевности и уметности, Иље Зиљберштејна, који саопштава да је проследио Максимовићево писмо Владимиру Бонч-Брујевичу - директору недавно отвореног московског Државног књижевног музеја. Двадесет седмог октобра дотични пише Максимовићу. Тако почиње њихова преписка која је трајала до фебруара 1934. године и у којој такође учествује власник рукописа Миодраг Обрадовић. Ако се размотре сва писма у

4 Францев, Владимир Андрејевич (1942) - слависта и историчар. Предавао у Донском и Варшавском универзитету и Карловом универзитету у Прагу. 
целини, у њима се могу издвојити две садржајне линије: прва - „прагматична“ и друга - „идеалистичка“.

Прво, о прогматизму, у троуглу продавац-купацпосредник.

Што се тиче Максимовића, он је заинтересован да добије провизију за стручно посредовање и непрестано убеђује совјетску страну да пожури и да понуди Обрадовићу „највећу за Вас прихватљиву цену“, јер се, наводно, појавио неки амерички претендент, који ће, ако се нађе у његовим рукама, онемогућити коришћење и истраживање манускрипта. Осим тога, Максимовић се плаши успостављања директних односа између купца и продавца, кога приказује као „луђака, коцкара и безобразника, који је спреман да прода МС првом који наиђе“. У једном од писама Максимовић чак нуди Бонч-Брујевичу неки компликовани поступак исплате који ће омести „Ноздрјова-junior да у задњем тренутку здипи новац. Јер он зна да са контрактом који ја имам тешко је да се бори у суду“. (РГАЛИ. Ф. 612. Оп. 1. Д. 3078. Л. 64)

Не знамо у коликој мери је Обрадовић заслужио упоређивање са једним од лица Гогољеве поеме „Мртве душе“, али је заиста покушавао да се отресе посредника „који је претерао постављајући захтеве“. „Веома вероватно - пише Обрадовић - да ћемо добити много више кад будемо успоставили непосредан контакт" (Москва Сербия, Белград - Россия: 410).

Захваљујући Бонч-Брујевичу купопродаја је на крају остварена на опште задовољство, иако је начин исплате од почетка забрињавао и совјетског директора. Не због евентуалних неправедности према Максимовићу, него због објективних околности. Како Бонч-Брујевич пише М. Обрадовићу, „Потребно се размислити на који начин да се изврши исплата суме... за Пушкинов рукопис који се код вас налази. На жалост, до данас у Југославији немамо нашег посланства, зато је у том погледу све теже 
него у другим земљама. Изволите нам указати како је боље урадити. Можда ћете одобрити да нам тај рукопис пошаљете дипломатском или препорученом пошиљком у Париз, на Југословенско посланство, с вашим налогом да се уручи опуномоћеном претставнику нашег посланства, које би истовремено исплатило 1500 долара. То би било најпростије и најбоље. Новац за вас спремљен је у нашем посланству у Паризу“. (Москва - Сербия, Белград - Россия: 411) Миодраг Обрадовић је 27 децембра 1933. године лично уручио рукопис службенику Совјетске Амбасаде у Паризу. Примајући рукопис благајна дипломатског претставништва исплатила је доносиоцу 38.000 француских франака, или око 125.000 тадашњих динара. Међутим, та погодба се не би успешно остварила без подршке совјетских дипломатских и највиших југословенских државних функционера, који су успели да превазићу постојећи међудржавни анимозитет.

Треба подсетити да је Москва од 1918. године на Југославију гледала као на „тамницу угњетених народа“, „један од делова ланца империјалистичког Версајског система“ (История Югославии: 35), као на „резултат жестоког гушења револуционарних тежњи народних маса“. (Сумарокова 1988: 506) Тај однос се још заоштрио после 9. јануара 1929, када је Кремаљ жигосао лични режим краља Александра Карађорђевића као „монархофашистичку диктатуру“. У таквом политичком контексту совјетски амбасадор у Француској Валеријан Довгаљевски (1885-1934) обраћа се југословенским представницима у Лиги народа. Њихове преговоре у писму Бонч-Брујевичу описује Мерле, помоћник Довгаљевског: „Друг Довгаљевски је у Женеви разговарао са сталним делегатом Југославије у Женеви (Константином - A. C.) Фотићем о проблему пушкиновог београдског рукописа. Фотић је одмах телефонирао министру спољних послова (Богољубу - А. С.) Јевтићу и обећао другу Довгаљевском 
да ће се проблем решити. Начелно је одлучено да ће у Београду министар спољних послова узети рукопис од Обрадовића, показати га Максимовићу, а да ће после тога послати рукопис дипломатском поштом у Париз, у Југословенску амбасаду“.

Совјетско-југословенска комуникација на високом нивоу није се зауставила ни после доласка манускрипта у Москву. У циљу сазнавања да ли је још нешто остало од Влајковићевих папира у Архиву Србије, Бонч-Брујевич је 25. новембра 1934. године са пуно куртоазије писао премијеру Краљевине Југославије Николи Узуновићу: „Ваша екселенцијо, обраћам Вам се у име нашег музеја... Уз благонаклоно учешће југословенске владе и Ваше непосредно учешће откупили смо за нас и за све словене драгоцени рукопис... итд.“ И, на крају: „Надам се да ћете нам и овог пута помоћи у нашем научном истраживању и да ћете нам преко Пушкина пружити руку братске помоћи, да наставимо наше заједничко истраживање једне од најзањимљивијих тема Руске, а мислим и свесловенске културе“.

Одговор је стигао тек крајем следеће 1935. године, и то преко амбасаде Чехословачке Републике у Москви. „Државни Архив у Београду саопштава да је поседовао велику колекцију аутографа различитих Руских писаца која је некад припадала Српском пуковнику Ђоки Влајковићу, али се она током Светског рата изгубила. Државни архив саопштава да је прегледао све своје збирке рукописа, али аутографи Пушкина и других Руских писаца међу њима нису пронађени“.

А сада о „идеалистичкој“ линији у преписци Максимовића и Бонч-Брујевича. Српски филолог је видео у совјетском великодостојнику не само човека од кога зависи да ли ће добити хонорар, него и интелектуалца који са њим дели љубав према уметности. У својим писмима он се њему обраћа као претставнику свог круга, наиме - прави књижевне алузије, цитира Плутарха, 
Гогоља, Пушкина, Достојевског. Верује да је московском директору заиста интересантно оно на чему он тренутно ради. У једном од писама Максимовић се жали: „Ја сам превише заузет, физички и морално готово исцрпљен због хитног посла. Двадесет првог новембра наш народ обележава стоту годишњицу од рођења нашег највећег песника и друштвеног радника Јована Јовановића Змаја. Ја сам задужен да у Матици српској држим предавање о њему као човеку и књижевнику“. (Москва-Сербия, Белград-Россия: 407)

Максимовић такође пише о Руском утицају на српску књижевност, о руско-српским културним и друштвеним везама у XIX веку, позивајући се на Лукијана Мушицког, Петра Петровића Његоша, Руске славјанофиле, чак и филозофа Владимира Соловјева, који је у Загребу писао један од својих радова. Спомињање православних архијереја-песника, егзалтираног религиозног мислиоца, као и Достојевског, који је у то време био скоро забрањен у СССР-у у писму човеку, који је потписао „Наредбу о црвеном терору“", сведочи о потпуној наивности Максимовића.

За разлику од њега, Директор књижевног музеја ништа не пише о свом књижевном укусу, уметничким утисцима и инспирацијама. Појављује се не као искрен саговорник, него као предузимач који жели да искористи сваког. Од Максимовића он једино очекује да не испушта из руку „Свеске Всеволожског“ и да му помогне у потрази за осталим изгубљеним рукописима руских писаца. Међутим, Бонч-Брујевич разуме да мора да се прилагоди српском филологу који је њихову преписку схватао не

5 „Црвени терор“ - комплекс казнених мера, које су бољшевици предузели током Грађанског рата (1918-1920) против „класних непријатеља“ и „контареволуционара“. Полазном тачком „црвеног терора“ сматра се наредба Савета народних комесара (СНК) од 5. септембра 1918. године. Бонч-Брујевич га је потписао у својству шеф канцеларије СНК. 
само као пословни контакт, него и као интелектуалну сарадњу двојице истомишљеника. Да би стекао поверење кореспондента и да би га наговорио да ради шта треба, Бонч-Брујевич се служи донекле вулгарним и јефтиним средствима. Наиме, он га моли да му пошаље своју слику, да му увек буде пред очима, док чита писма и пише одговоре. Осим тога, Бонч-Брујевич сматра да било који Србин, укључујући Ноздрјова-јуниора и „руководиоца једног од великих словенских народа“" Узуновића, може да се освоји ако се апелује на његово русофилство и осећај словенске узајамности. У једном од писама Максимовићу пише да „би нама словенима било јако непријатно ако би се рукопис нашег генијалног песника нашао у рукама Американца“. У другом, Бонч-Брујевич се захваљује на исечцима из периодике и прича да је за његов музеј драгоцен сваки „одраз стваралаштва наших писаца у $\delta р a \bar{u}-$ ским словенским литиератирама“. (Москва-Сербия, Белград-Россия: 413)

Треба подсетити да је баш у то време - 20-их година 20. века и у првој половини 30-их година славистика у Совјетском Савезу - и филологија и историја - жигосана као „реакциона, фашистичка, расистичка наука“. Зато је 1934. године био затворен Славистички институт у Лењинграду, а научници су изложени репресији. (Досталь 2007: 114-140) Бонч-Брујевичево славенофилство било је валута само за спољну употребу.

За разлику од лицемерног друга директора, Јован Максимовић је заиста био искрен русофил. „Веома сам Вам захвалан - пише он Бонч-Брујевичу пошто је добио од њега књигу о Гетеу - Читав живот живим са Русијом, верујем у њу слично Достојевском. Ваш поклон је као зрак светлости у царству мрака (цитат из позоришног комада Александра Островског). Богзна шта пишу о Русији, али ми тврдо знамо да ће Русија ускоро развити свој огроман, једини у свету потенцијал. Ово је потребно 
нама словенима и читавом свету који се дави без спасилачког словенског и Руског генија“. (Москва-Сербия, Белград-Россия: 414)

Нема сумње да је Максимовићево русофилство одиграло одлучујућу улогу у враћању Пушкиновог рукописа у Русију. „Тужно ми је да се растајем са овом драгоценошћу. Али ипак се радујем да се манускрипт враћа отаџбини. Пушкинова душа осетиће олакшање“.

\section{Извори и литература}

\section{Необјављени извори}

Российский государственный архив литературы и искусства. Ф. 612 (Государственный литературный музей).

\section{Објавтени извори}

„Московски Музеј уметничке литературе, критике и публицистике откупио је „Београдски“ Пушкинов рукопис за 38.000 франака“. Политика (назив гласила италиком). 12. јануар 1934.

„Москва-Сербия, Белград-Россия“. Сборник документов и материалов. Том 4. Русско-сербские отношения. 1917-1945 гг. (италиком све после наводника довде) Авторы-составители: Тимофејев Алексеј, Милорадовић

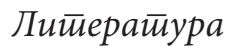

Бранденбергер Д.Л. Национал-большевизм. Сталинская массовая культура и формирование русского национального самосознания. 1931-1956. СПб., 2009.

Домгерр Л. Л. Из истории советского академического издания полного собрания сочинений Пушкина 1937-1949 гг. (Материалы и комментарии) (http://lib2.pushkinskijdom. ru/Media/Default/PDF/PUSH/Klassiki/Domgerr-1987a.pdf)

Досталь М. Ю. Славистика между пролетарским интернационализмом и славянской идеей (1917-1941) // Славянский альманах 2006. М., 2007. С. 114-140. 
История Югославии. II. М., 1963.

Јовановић, М. Досетьвате руских избеглииа у Краљевину СХС 1919-1924. Београд, 1996.

Йованович, М. Русская эмиграция в Югославии. М., 1996.

Йованович, М. Русская эмигращия на Балканах (1920-1940) М., 2005.

Јовановић, Мирослав. Срби о Русији и Русима: Од Елизаветее Пейровне gо Влаgимира Пуииина (1750-2010) - Анйолоіија. Београд, 2011.

Козлитин, В. Д. Русская и украинская эмигращия в Югославии. Киев, 1998.

Летописи Государственного литературного музея: Кн. 1. Пушкин. М., 1936

Материаль по истории первого собрания стихотворений Пушкина (1826) // Литературное наследство. Кн. 16-18. M., 1934. 825-843.

Милорадовић, Горан. „Културне везе јаче од политичких: Срби и Руси 1917-1945. године“ // „Москва-Сербия, Белград-Россия“" Сборник документов и материалов. Том 4. Русско-сербские отношения. 1917-1945 гг. (италиком све после наводника довде). Авторы-составители: Тимофејев Алексеј, Милорадовић Горан, Силкин А. А. М., 2017. 54-71.

Сумарокова, М. М. Югославия. Политические отношения в Королевстве СХС (1921-1928 гг.) // Политические системы в странах Центральной и Юго-Восточной Европы. 19171929 гг. (италиком наслови) М., 1988. 506. 


\section{Aleksandar Silkin}

\section{THE LEGACY OF A. S. PUSHKIN AS “THE BRIDGE” BETWEEN THE SOVIET UNION AND THE KINGDOM OF YUGOSLAVIA 1933-1935}

The Bolshevik coup (1917) and the Civil War in Russia led to the disruption of traditional civil and political relations between Serbs and Russians. Cultural relations between the two nations in the interwar period were mainly maintained as a result of numerous colonies of Russian refugees located in Yugoslavia. However, it is precisely in this cultural sense that the emigration was not able to compensate for the "forever" lost Russia and fully meet the appropriate curiosity of Serbian intelligence. The interest of its representatives in establishing contacts with Soviet's scientific and cultural institutions is reflected in the correspondence between the famous Serbian philologist Jovan Maksimović and director of the Moscow State Literary Museum Vladimir Bonch-Bruyevich. The letters mainly discuss the way in which the lost manuscript of A. S. Pushkin (the so-called Volume Vsevolozhsk), which was found in the house of a minor Yugoslav officer Miodrag Obradović, could be returned to Russia. The fact that it represents a part of the Russian literature genius' legacy further raises our interest toward the documents that are kept in the Russian State Archive of Literature and Art. However, the way in which the manuscript was purchased/ sold is equally important for the historians. It was completed successfully only through the participation of senior Yugoslav and Soviet diplomatic officials who have realized the importance of enterprise and, despite the absence of official relations, have established informal bilateral contacts within the framework of the League of Nations.

Key words: Alexander S. Pushkin, Soviet Union, Yugoslavia, cultural and diplomatic relations 